\section{Method for Preparing YAC Sublibraries in a Plasmid Vector}

\section{BioTechniques 20:372-374 (March 1996)}

The ability to generate representative libraries of small DNA fragments from a particular yeast artificial chromosome (YAC) is useful in a number of strategies associated with positional cloning. These include candidate gene identification by sample sequencing (2), isolation of CA/GT or triplet repeats and the identification of YAC termini clones. Since a 400-kb YAC requires only 800 clones of 500-bp insert size to provide one-time coverage, relatively small numbers of recombinants, even in the presence of significant yeast DNA contamination, are required to propagate a representative library. Preparation of purified YAC DNA is, however, a time-consuming process that provides a limited amount of material for fractionation and subsequent subcloning.

We describe a simple 3-step procedure that we have successfully used to prepare libraries from both cosmid and P1 genomic DNA clones, which enables this restricted supply of YAC DNA to be utilized for library construction. In the first step, the YAC DNA is isolated by preparative pulsed field gel electrophoresis (PFGE). Next, the prepared DNA is sonicated to yield a random collection of small fragments, which, after end-repair with T4 DNA polymerase, are selectively precipitated with a polyethylene glycol (PEG) mixture. The advantage of the PEG step is that only DNA segments greater than $100-150 \mathrm{bp}$ are precipitated, leaving smaller DNA fragments in the supernatant. In the final step, the resuspended DNA is efficiently cloned into a plasmid vector using a pCR-Script ${ }^{\mathrm{TM}}$ SK(+) cloning kit (Stratagene, La Jolla, CA, USA) developed for PCR products. This method involves the addition of blunt-ended DNA into a reaction mixture containing T4 ligase, the rare 8-base cutter SrfI and pCR-Script $\mathrm{SK}(+)$ vector predigested with the SrfI enzyme. Presence of the restriction endonuclease enables a high, steady-state concentration of digested vector to be maintained, accounting for the reduced level of nonrecombinants following transformation of the ligation reaction.

The method we describe differs significantly from a recently reported protocol for library construction in which the YAC DNA fragments, prepared by shearing of PFGE-isolated DNA in a French pressure cell and subsequent fractionation by excision from an agarose gel, are cloned into the M13 mp18 vector (6). We shear the isolated YAC DNA by sonication and then achieve fractionation of the fragmented DNA by a simple precipitation step, which is rapid and ensures that DNA losses are minimized. In addition, we employ a plasmid for generating our YAC sublibraries; such vectors are much easier to handle and store than M13 filamentous phage.

The libraries we have prepared using our method have consisted of at least $10^{5}$ recombinant clones with insert sizes ranging from 0.15 to $1.5 \mathrm{~kb}$. Nonrecombinant white clones have ranged from $8 \%-24 \%$ of the total colonies picked, a feature attributable to the low concentration of fragmented DNA used in the ligation reaction. Nonrecombinant blue clones usually account for approximately $40 \%$ of colonies plated on selective media.

\section{Protocol for Library Construction}

1. Isolate YAC DNA (400-800 ng in a volume of $100-200 \mu \mathrm{L}$ ) with the
GlassMAX $^{\circledR}$ reagent , system (Life Technologies, Gaithersburg, MD, USA), following preparative PFGE on a Hoefer Hula system (Hoefer Pharmacia Biotech, San Francisco, CA, USA) as described by Riley (3).

2. Randomly fragment the isolated YAC DNA using an ultrasonic processor (Model No. XL2020; Heat Systems, Farmingdale, NY, USA) with a cup-horn sonicator. Treat the DNA in 1 or 2 ten-second pulses on an output setting of 4.5. End-repair the DNA fragments by the appropriate addition of $5 x$ T4 DNA polymerase buffer, dNTPs to a final concentration of $200 \mu \mathrm{M}$ and $\mathrm{T} 4$ DNA polymerase (Boehringer Mannheim, Lewes, Sussex, England, UK) to a final concentration of $0.02 \mathrm{U} / \mu \mathrm{L}$. Incubate for either $30 \mathrm{~min}$ at room temperature or overnight at $16^{\circ} \mathrm{C}$. Precipitate the DNA by addition of an equal volume of PEG solution (26.2\% PEG $8000,6.6 \mathrm{mM} \mathrm{MgCl} 2,0.6 \mathrm{M}$ sodium acetate, $\mathrm{pH}$ 5.2) (7), mix and let stand at room temperature for $5 \mathrm{~min}$; follow this by centrifugation at $13000 \times g$ for 5 $\mathrm{min}$. Carefully remove the supernatant, wash the precipitated DNA with 100 $\mu \mathrm{L}$ of $70 \%$ ethanol, dry and then resuspend in a volume of $10 \mu \mathrm{L} \mathrm{H}_{2} \mathrm{O}$. Approximately $200 \mathrm{ng}$ of this DNA should be visible as a smear centered around $400-500 \mathrm{bp}$ on an ethidium bromidestained agarose gel $(1 \%)$.

3. Clone the blunt-ended DNA using a pCR-Script $\mathrm{SK}(+)$ cloning kit for

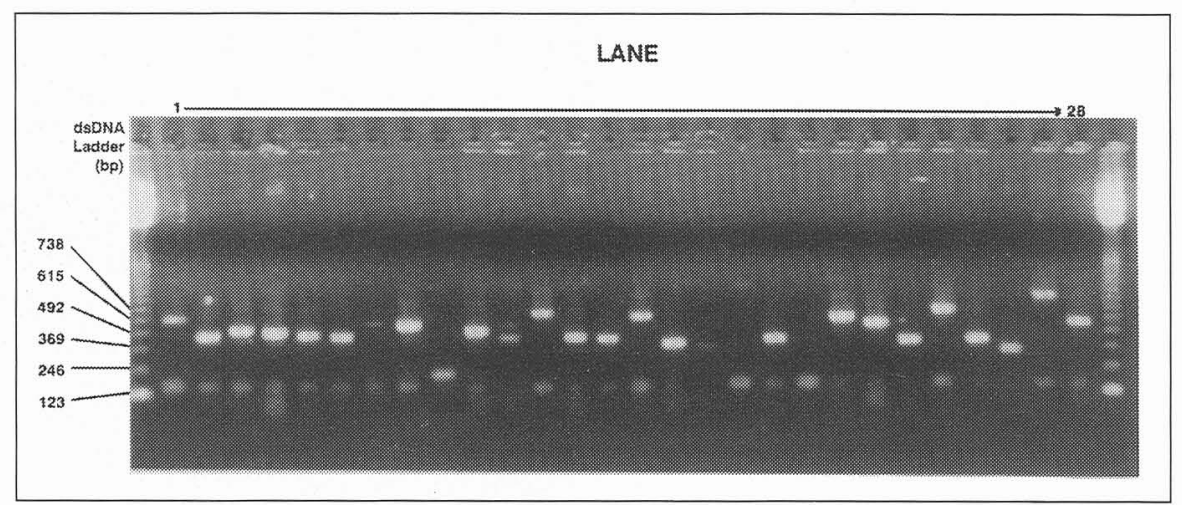

Figure 1. Direct PCR screen of 28 colonies from a human YAC pCR-Script SK(+) sublibrary using flanking polylinker T3/T7 "Universal”" primers. Each colony was directly toothpicked into a $10-\mu \mathrm{L}$ PCR mixture containing $1 \mu \mathrm{L}$ each of T3 $(10 \mu \mathrm{M})$ and T7 $(10 \mu \mathrm{M})$ primers; $1 \mu \mathrm{L}$ dNTPs ( 2 mM each); 1 $\mu \mathrm{L} 10 \times$ PCR buffer (including $15 \mathrm{mM} \mathrm{MgCl}_{2}$ ); $5.95 \mu \mathrm{L}$ distilled water; $0.05 \mu \mathrm{L}$ AmpliTaq ${ }^{\circledR}$ DNA polymerase $(5 \mathrm{U} / \mu \mathrm{L})$ (Perkin-Elmer/Applied Biosystems Division). Reaction mixtures were cycled 35 times using the following program: $94^{\circ} \mathrm{C}$ for $0.5 \mathrm{~min}, 50^{\circ} \mathrm{C}$ for $0.5 \mathrm{~min}$ and $72^{\circ} \mathrm{C}$ for $2 \mathrm{~min}$. Note that the vector polylinker contributes an additional $166 \mathrm{bp}$ to the product size. Lane 9 contains a PCR product generated from a nonrecombinant clone. The products in lanes 7,11,17 and 18 were poorly amplified, and, as a consequence, are barely visible with the ethidium bromide staining. 
polymerase chain reaction (PCR) products (Stratagene). Ligate the DNA for $2-3 \mathrm{~h}$ according to the manufacturer's instructions with the following: $5 \mu \mathrm{L}$ pCR-Script vector $(10 \mathrm{ng} / \mu \mathrm{L}) ; 1 \mu \mathrm{L}$ $10 \times$ universal buffer; $0.5 \mu \mathrm{L}$ rATP $(10$ $\mathrm{mM}) ; 2.5 \mu \mathrm{L}$ end-repaired, fragmented YAC DNA (50-200 ng); $1.0 \mu \mathrm{L}$ Srfl restriction endonuclease $(10 \mathrm{U} / \mu \mathrm{L})$; and $1.0 \mu \mathrm{L}$ T4 DNA ligase $(4 \mathrm{U} / \mu \mathrm{L})$. Following the incubation period, transform $1.0-\mu \mathrm{L}$ aliquots of the ligation mixture into $100-\mu \mathrm{L}$ volumes of XL1-Blue supercompetent $E$. coli (Stratagene) using standard protocols (4). Plate out transformations on media containing ampicillin, tetracycline, 5-bromo-4chloro-3-indolyl- $\beta$-D-galactoside (Xgal) and isopropyl-1-thio- $\beta$-D-galactoside (IPTG) allowing blue/white selection of nonrecombinant/recombinant clones (4).

Clones from prepared YAC sublibraries are sequenced on $\mathrm{ABI} 373$ auto- mated DNA sequencers (PerkinElmer/Applied Biosystems Division, Foster City, CA, USA), using unpurified PCR products as templates, as described by Trower et al. (5). Sequences are compared to protein and nucleic acid databases with the BLASTX and BLASTN programs (1). Typically between $50 \%$ and $60 \%$ of the sequences obtained are of human origin, though the actual figure depends on how closely a particular YAC migrates to one of the yeast host's chromosomes during the PFGE step. The amount of yeast contamination may be reduced to less than $10 \%$ by further rounds of PFGE (6), though this must be balanced by potential losses of DNA due to the additional purification steps.

Results from a PCR screen of 28 randomly picked white colonies from a YAC sublibrary prepared using the above protocol are shown in Figure 1. PCR products were generated from 27 of the 28 picked clones. Of these, 26 of the clones were recombinant, with insert sizes ranging from 0.15 to $1.0 \mathrm{~kb}$ with a mean of $0.45 \mathrm{~kb}$.

\section{REFERENCES}

1.Altschul, S.F., W. Gish, W. Miller, E.W. Myers and D.J. Lipman. 1990. Basic local alignment search tool. J. Mol. Biol. 215:403410.

2.Claverie, J.-M. 1994. A streamlined random sequencing strategy for finding coding exons. Genomics 23:575-581.

3.Riley, J.H. 1995. Purification of YAC DNA using the Glassmax system. Focus 17:74-75.

4.Sambrook, J., E.F. Fritsch and T. Maniatis. 1989. Molecular Cloning: A Laboratory Manual, 2nd ed. Cold Spring Harbor Laboratory Press, Cold Spring Harbor, NY.

5.Trower, M.K., D. Burt, I.J. Purvis, C.W Dykes and C. Christodoulou. 1995. Fluorescent dye-primer cycle sequencing using unpurified PCR products as templates; development of a protocol amenable to highthroughput DNA sequencing. Nucleic Acids Res. 23:2348-2349.

6.Vaudin, M., A. Roopra, L. Hillier, R. Brinkman, J. Sulston, R.K. Wilson and R.H. Waterston. 1995. The construction and analysis of M13 libraries prepared from YAC DNA. Nucleic Acids Res. 23:670-674.

7.Waterston, R., C. Martin, M. Craxton, C. Huynh, A. Coulson, L. Hillier, R. Durbin, P. Green et al. 1992. A survey of expressed genes in Caenorhabditis elegans. Nature Genet. 1:114-123.

We would like to thank members of the Molecular Genetics Unit, Dept. Medicine, University of Cambridge School of Clinical Medicine, Cambridge, England, for advice on sonication conditions. Address correspondence to Michael $K$. Trower, Genomics Unit (6G210), Disease Sciences Division, Glaxo-Wellcome Medicines Research Centre, Stevenage SG1 2NY, England, UK. Internet: mkt26670@ggr.co.uk

Received 27 February 1995; accepted 25 September 1995.

Michael K. Trower, Ian J. Purvis, Colin W. Dykes and John H. Riley Glaxo-Wellcome Medicines Research Centre Stevenage, England, UK 